\title{
29. RECENT TO MIDDLE MIOCENE DIATOM PRODUCTIVITY AT SITE 907, ICELAND PLATEAU ${ }^{1}$
}

\author{
Bjørg Stabell² and Nalân Koç ${ }^{3}$
}

\begin{abstract}
Surface water productivity at Ocean Drilling Program Site 907 has been assessed from total diatom abundance and Chaetoceros resting spore frequency. The sediments are divided into four intervals based on relative diatom abundance. Intervals 1 and 4 are mainly barren of diatoms. Interval 2 shows a highly fluctuating abundance pattern, whereas Interval 3 is a biosilicarich middle to late Miocene (13.7-10.1 Ma) sediment containing abundant diatoms dominated by Chaetoceros resting spores. Resting spores of Chaetoceros are classified according to their forms. The round to elongate spores with smooth surfaces or spines/ridges dominate the assemblage throughout the biosilica-rich interval. The transition from the diatom barren interval to the biosilica-rich interval at about $13.7 \mathrm{Ma}$ is characterized by extremely high $(100 \%-85 \%)$ Chaetoceros spore content. The late Miocene to late Pliocene (10.1-3.0 Ma) interval with highly variable diatom content is characterized with lower Chaetoceros percentages than in the biosilica-rich interval. We infer that the period between 13.7 and $10.1 \mathrm{Ma}$ reflects high surface water productivity at Site 907 . The high percentage of Chaetoceros resting spores at this interval suggests upwelling of nutrient-rich subsurface waters during this period.
\end{abstract}

\section{INTRODUCTION}

The Norwegian-Greenland Sea is considered to have two distinct Tertiary biosilica-enriched intervals that occurred during the Eocene and the Miocene. Sediments characterized as biosiliceous rich/diatom ooze have been reported earlier from the Miocene sections of Deep Sea Drilling Project (DSDP) Sites 338, 341, 342, and 348, and from Ocean Drilling Program (ODP) Sites 642 and 643. Preservation of these biosiliceous sediments is interpreted to indicate the presence of highly productive surface waters during these times. Surface water productivity, by controlling the supply rate of siliceous valves to the seafloor and the silica saturation level of the pore waters, exerts a primary control on the abundance of siliceous microfossils in the sediments (Schink et al., 1974; Broecker and Peng, 1982; Pokras and Molfino, 1986). Seawater is typically undersaturated with respect to silica (Lisitzin, 1972; Heath, 1974). Therefore, most of the siliceous skeletons produced in the photic zone dissolve before entering the sedimentary record (Berger, 1976). The impact of this dissolution on the geological record is a function of relative rather than absolute loss of siliceous valves (Pokras, 1986). The rates of biogenic silica accumulation through time are, therefore, a general indication of surface water productivity changes. The recovery of a Holocene to middle Miocene near-continuous sediment sequence with a pristine paleomagnetic record at ODP Site 907 on the Iceland Plateau gave us a unique opportunity to study the evolution of Neogene surface water productivity as assessed from total diatom abundance and Chaetoceros resting spore fluctuations.

ODP Leg 151 is the third DSDP/ODP leg in the NorwegianGreenland Sea. DSDP Leg 38 cored 17 sites. However, due to spotand rotary-coring techniques employed at these sites, the material recovered was discontinuous and lacked paleomagnetic stratigraphy. ODP Leg 104 (Eldholm, Thiede, Taylor, et al., 1987) concentrated on

'Thiede, J., Myhre, A.M., Firth, J.V., Johnson, G.L., and Ruddiman, W.F. (Eds.), 1996. Proc. ODP, Sci. Results, 151: College Station, TX (Ocean Drilling Program).

'Department of Geology, University of Oslo, P.O. Box 1047 Blindern, N-0316 Oslo, Norway. bstabell@geology.uio.no

${ }^{3}$ Department of Geology, University of Bergen, Allégaten 41, N-5007 Bergen, Norway. three holes on the Vøring Plateau. These sites were drilled with the advanced hydraulic piston corer (APC) with high recovery and good sample quality. However, these sequences include a number of Neogene hiatuses, and the interpretation of the paleomagnetic record is problematic. ODP Leg 151 employed APC/XCB (extended core barrel) coring techniques and retrieved $100 \%$ recoveries with very good sample quality. Biosiliceous-rich sediments were retrieved from Sites 907, 908, and 913.

Samples from the diatom-rich Oligocene/Eocene interval at ODP Site 913 were processed in an attempt to assess the surface water productivity during these times and to compare it with the diatom assemblage at Site 907. The diatoms at Site 913 were, however, so fragmented that they were not suitable for any quantitative study. It has been difficult to compare the results from Site 907 with available information from DSDP Leg 38, as the diatom investigation from that leg was a pioneering study on Norwegian Sea diatom biostratigraphy and, therefore, only minimally dealt with abundances and Chaetoceros spores.

Site 907 is located on the Iceland Plateau in the southwestern part of the Norwegian-Greenland Sea, between the Kolbeinsey Ridge and the Jan Mayen Ridge (Fig. 1). The site represents part of the western extension of a paleoenvironmental transect from the Norwegian (ODP Leg 104) to the Greenland continental margin. The diatom abundance pattern at ODP Site 907 was studied to understand the temporal and spatial distribution of Neogene biosiliceous production in the Norwegian-Greenland Sea.

\section{MATERIALS AND METHODS}

For relative diatom abundances at least one sample was examined from each core section $(1.5 \mathrm{~m})$. All samples were treated with $37 \%$ $\mathrm{HCl}$ and $30 \%$ hydrogen peroxide and washed with distilled water until a $\mathrm{pH}$ of 7 was achieved. Strewn slides of acid-cleaned material were examined at $400 \times$. Species were recorded as abundant (A) if six or more specimens were present in one field of view at $400 \times$; common $(C)$ if one to five specimens occurred in one field of view; few (F) if one to four specimens occurred in five fields of view; or rare (R) if one to 10 specimens occurred per horizontal traverse. 


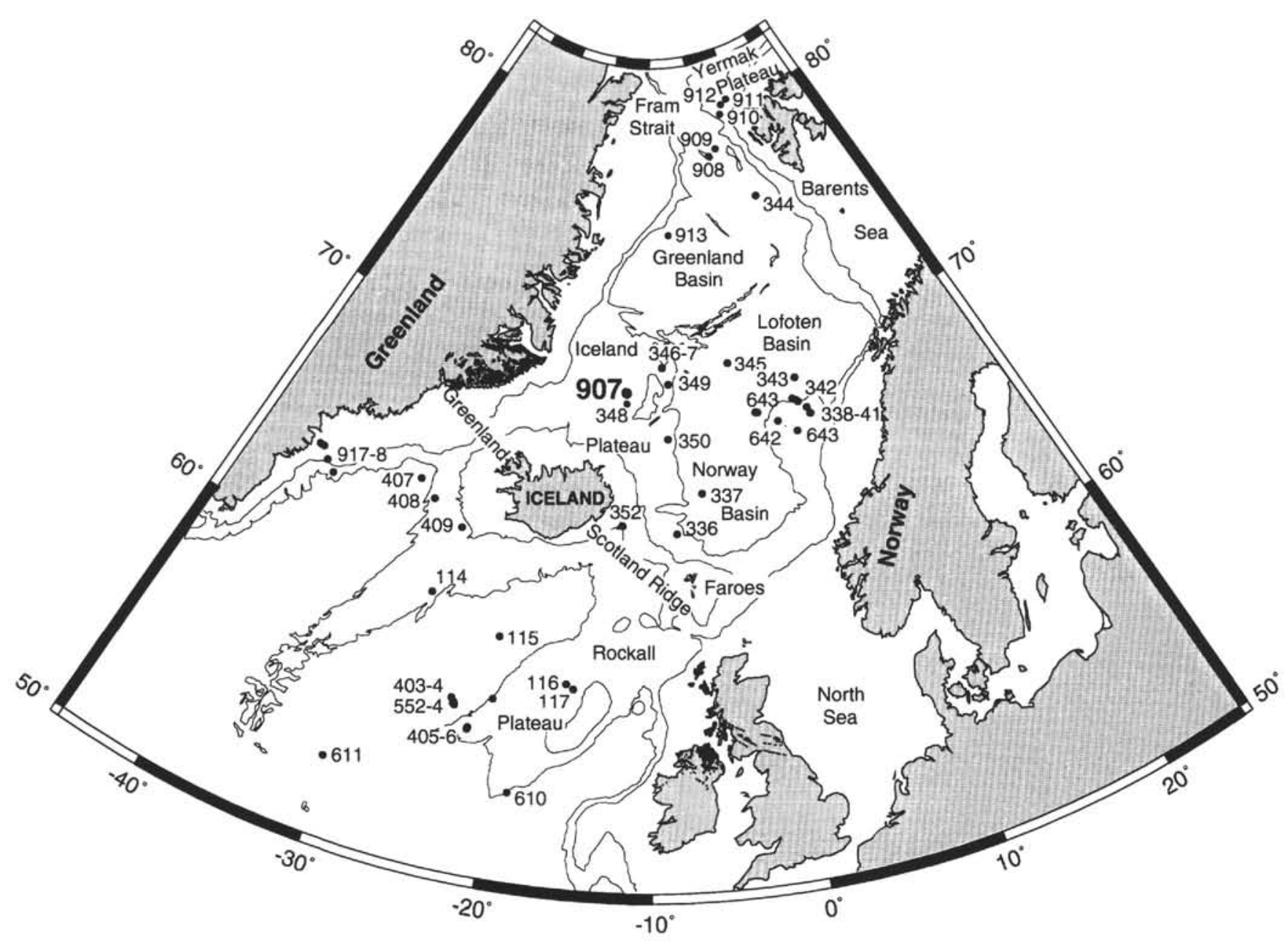

Figure 1. Location map of Site 907 with DSDP/ODP sites marked.

For the biosilica-rich interval, the diatom samples were prepared based on the procedure described in Kaland and Stabell (1981), adding Lycopodium spores as a marker for absolute control in quantitative estimates. About $0.02 \mathrm{~g}$ dry sediment was oxidized in $\mathrm{H}_{2} \mathrm{O}_{2}$ and repeatedly washed. Calcareous matter was removed with $\mathrm{HCl}$. For $0.02 \mathrm{~g}$ dry sediment about $2.5 \times 10^{5}$ Lycopodium spores were added. With this method, only the weight of the sediment sample and the number of Lycopodium spores added need to be known, and the number of diatom valves per gram dry sediment can then be calculated. Diatoms on the quantitative slides from Interval 3 were identified and counted. The percent distribution of resting spores of Chaetoceros (see Figs. 4, 5) are based on these counts.

The sediment in this core is, however, characterized by numerous volcanic ash layers. Therefore, absolute abundances in this environment more likely reflect fluctuations in ash content rather than diatom productivity. Mass accumulation rates were, therefore, not calculated. Ages for Site 907 are mainly based on magnetostratigraphy (Koç and Scherer, this volume).

\section{RESULTS}

The relative total diatom abundance pattern of Site 907 can be divided into four major intervals (Fig. 2). Interval 1, between 0 and 55 meters below seafloor (mbsf) (Pleistocene to upper upper Pliocene), is mainly barren except for the top of the core ( 0.04 and $0.13 \mathrm{mbsf}$ ).
Interval 2, between 55 and 120 mbsf (upper upper Pliocene to lower upper Miocene), exhibits a fluctuating diatom abundance pattern (from barren to abundant). Interval 3, between 120 and $198 \mathrm{mbsf}$, consists of continuously abundant diatoms. Interval 4 , the lowermost part of the hole between 198 and $220 \mathrm{mbsf}$, is barren of diatoms. This division also corresponds well with the lithologic units. The sediments recovered at Site 907 were divided into five lithologic units based primarily on the varying amounts of biogenic and siliciclastic material and volcanic glass (Myhre, Thiede, Firth, et al., 1995). The pattern of diatom deposition observed from Site 907 shows an evolution from middle Miocene to Holocene, with high biosilica deposition through the middle-early late Miocene, fluctuating biosilica deposition through the middle late Miocene-middle late Pliocene and very sporadic biosilica deposition through the middle late PlioceneHolocene.

\section{IRD Record and Diatom Abundance}

Changes in diatom abundance patterns correlate well with increase of ice-rafted detritus (IRD) in the area (Fig. 3). The interval containing diatoms have a generally lower gamma-ray attenuation porosity evaluator (GRAPE) density than the intervals where there are no or very sporadic occurrences of diatoms. No IRD is recorded in the diatom-rich interval occurring between 120 and $198 \mathrm{mbsf}$, indicating warm surface waters during this period of high surface water productivity in the area during the middle and early late Miocene. 


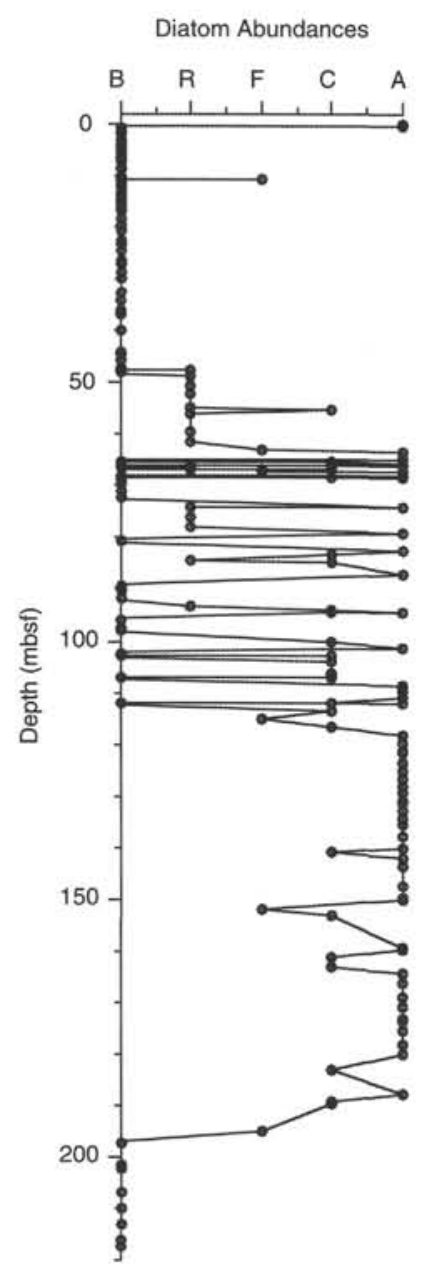

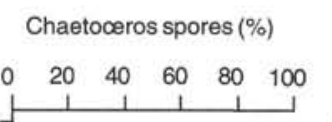

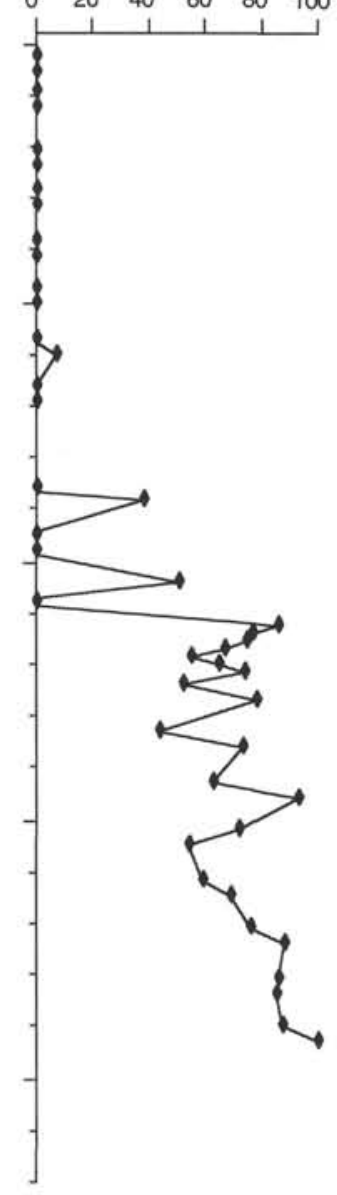

Lith.

unit

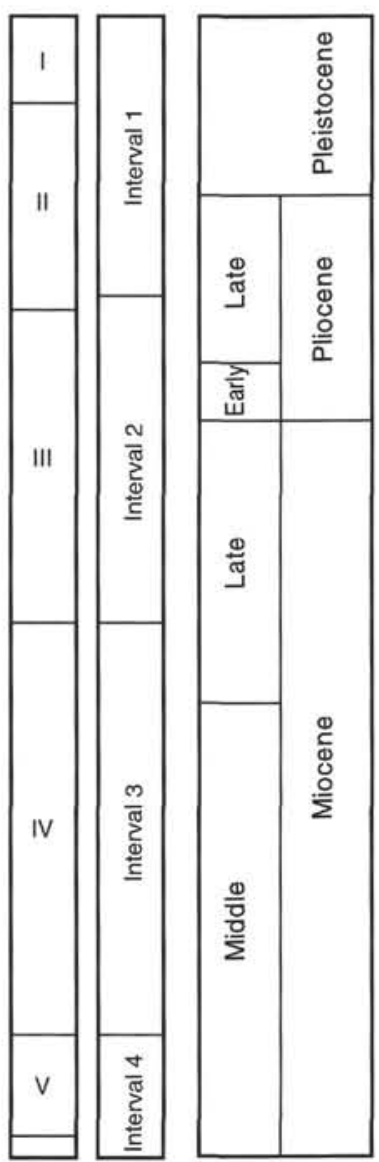

Figure 2. Relative diatom abundances (see text for abbreviations) and percentage distribution of Chaetoceros resting spores at Site 907 . No resting spores indicates samples also barren in diatoms.
Fluctuating diatom abundances are recorded between 10 and $2.9 \mathrm{Ma}$. The first IRD at Site 907 is recorded at 118 mbsf (at about $10 \mathrm{Ma}$; Koç and Scherer, this volume) corresponding to the start of fluctuating diatom abundances indicating variable surface water conditions in response to waxing and waning ice sheets in the surrounding land masses. Low concentrations of IRD persist until $2.9 \mathrm{Ma}$. Fronval and Jansen (this volume) argue that the period between 6 and 2.9 Ma represents the onset of middle-sized glaciations in the Northern Hemisphere. Diatoms disappear nearly entirely from the sedimentary record of Site 907 as the IRD input to the area intensified around 2.9 $\mathrm{Ma}$, indicating the presence of large-scale glaciations around the Nordic Seas (Fronval and Jansen, this volume).

\section{Chaetoceros Resting Spores at Site 907}

Interval 4 has little or no biogenic components (Myhre, Thiede, Firth et al., 1995) and is directly overlain by a biosiliceous-rich unit (Unit 3 = Interval 3; Fig. 2). Interval 3 was studied in most detail as this interval showed a continuous high diatom abundance. Diatom resting spores constitute a high percentage of the diatom assemblage in this high-abundance interval. The results of the absolute abundance calculations are shown in Fig. 4A. Total abundances fluctuate from less than 10 to nearly 200 million diatoms per gram dry sediment. These fluctuations are believed to reflect fluctuations in ash content rather than diatom productivity. The biosilica-rich Interval 3 was investigated semi-quantitatively to quantify fluctuations in upwelling by studying variations in the percentage of Chaetoceros rest- ing spores at this interval (Fig. 4B). All but one sample at Interval 3 have more than $50 \%$ resting spores. The percent distribution of resting spores shows a gradual decrease from the bottom of this interval (at $193 \mathrm{mbsf}$ ) with $100 \%$ resting spores to the middle (at $155 \mathrm{mbsf}$ ) with about $50 \%$ resting spores. Above 155 mbsf, resting spore percentages generally fluctuate between $50 \%$ and $80 \%$.

In an attempt to distinguish at least the major spore types, the resting spores were grouped after morphological characteristics (PI. 1). Group A is round to elongate. A1 has a fairly smooth surface (Pl. 2), resembling $C$. lauderi of Hargraves (1979). A2 has a surface with spines/ridges (PI. 3), resembling Xanthiopyxis of Hargraves (1986). Group B is of the more traditional Chaetoceros type with setae (Pl. 4). Group C is the Chaetoceros/Pterotheca types, Group D is Chaetoceros cinctus types, Group E is a type with a rough surface, and Group F is other (spores not given any other category).

Groups $\mathrm{A} 1$ and $\mathrm{A} 2$ are the dominant groups throughout the studied interval (Fig. 5). Al constitutes between $40 \%$ and $95 \%$ of the total resting spores, while A2 makes up from less than one to $34 \%$ of the total. Together they comprise between $61 \%$ and $95 \%$ of the total resting spore assemblage. Group B has its highest percentages $(15 \%-$ $20 \%$ ) in the upper and lower part of the investigated section, whereas Group $\mathrm{C}$ has high percentages (as much as 25\%) between 130 and 160 mbsf. Group D is recorded in three samples with around 5\% contribution, while Group E has only been recognized in one sample (126.5 mbsf) where it comprised 13\% of the resting spore assemblage. Resting spores not assigned to a specific group vary between $0 \%$ and $17 \%$. 


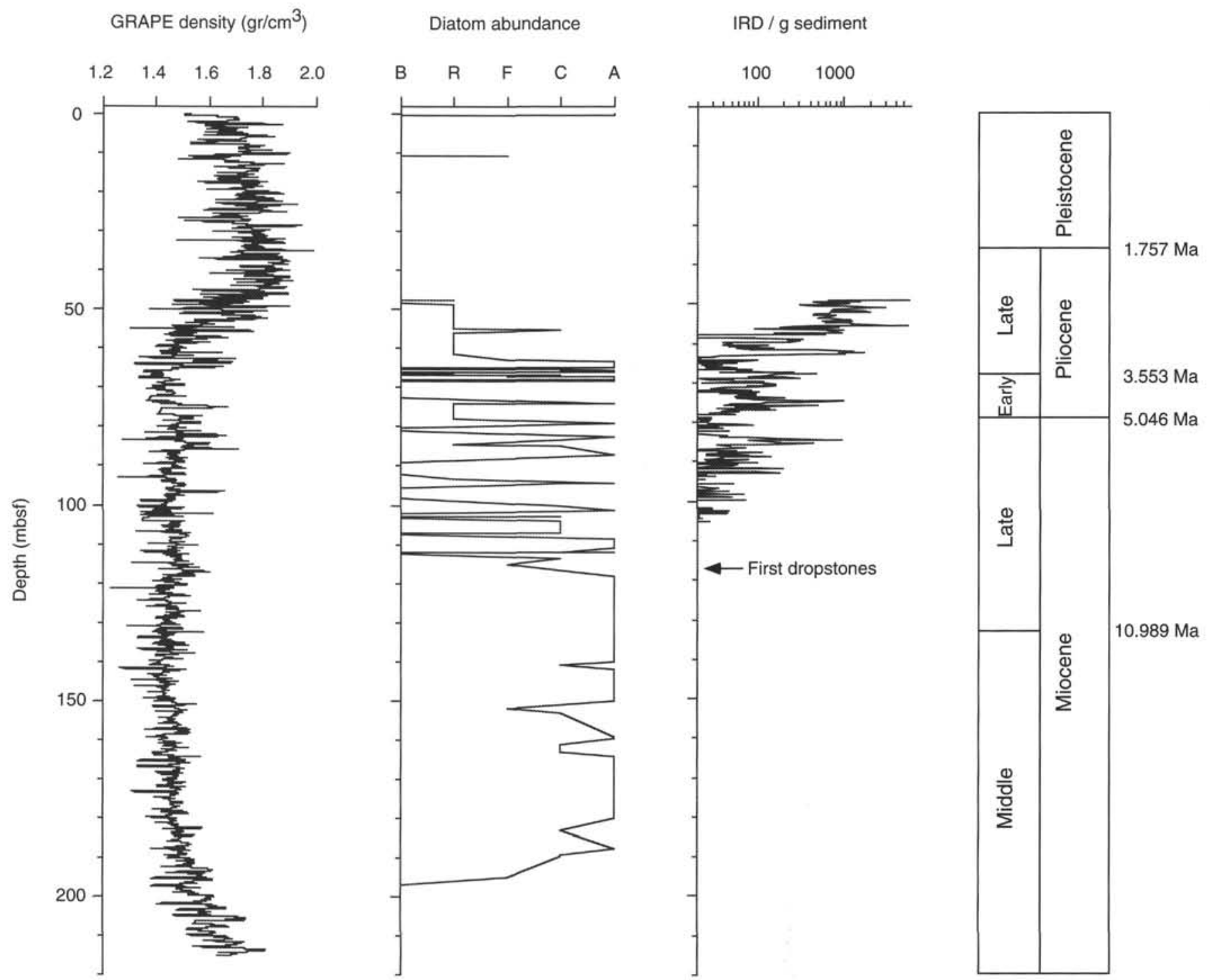

Figure 3. GRAPE data, diatom abundances, and ice-rafted detritus (IRD) content at Site 907.

\section{DISCUSSION}

\section{Chaetoceros Resting Spores and Upwelling}

Spores of the genus Chaetoceros are usually taken as a measure of diatom productivity (Sancetta, 1982; Abrantes, 1988). These spores are believed to characterize the late stage production in coastal upwelling areas, but it is also possible that in an offshore setting they indicate some degree of erosion and lateral advection from shelf sediments (Sancetta et al., 1992). Akiba (1986) discusses the possibility that mass occurrences of Chaetoceros resting spores might indicate a shallowing basin environment. Within the water column, diatom resting spores are most often abundant in coastal phytoplankton communities (Hargraves, 1979). Chaetoceros species have been considered as being associated with the last stage of species succession, dominating the assemblage in upwelling regions when nutrients are nearly exhausted in the euphotic zone (Margalef, 1978). These spore assemblages can generally account for a major fraction of the opaline sediment component in coastal upwelling regions. Stockwell and Hargraves (1986) state that even though Chaetoceros resting spores can be an important component of marine sediments as well as a spe- cies-specific and useful taxonomic tool, within the thanatocoenoses, the group has generally been lumped taxonomically into the broad category "Chaetoceros spores" by most authors. Whether a fossil specimen is a spore or vegetative cell has been subject of some controversy for many years (Hargraves, 1986). Earlier investigations on resting spores dealt traditionally with their biostratigraphy (Schrader and Fenner, 1976). Taxonomic references with good photographs are given, but there is little information on the distribution and abundances of the resting spores except as Chaetoceros spores. "Resting spores" in this study refer to diatom resting spores that differ markedly from vegetative cells. However, we concentrate the study especially on those usually characterized as belonging to the genus Chaetoceros.

Although the cores have not been sampled in detail, it is interesting to note (Figs. 2, 3) the transition from no diatoms at $199 \mathrm{mbsf}$ via a low-abundance sample with only resting spores at $193 \mathrm{~m}$ to a moderate-abundance sample with about $15 \%$ diatoms and about $85 \%$ resting spores at $190 \mathrm{mbsf}$. This transition can best be explained by a dominance of Chaetoceros spp. and related species being the first diatoms to appear from the time biosilica is preserved in the sediments Only the resting spores from these presumable easily dissolved veg- 


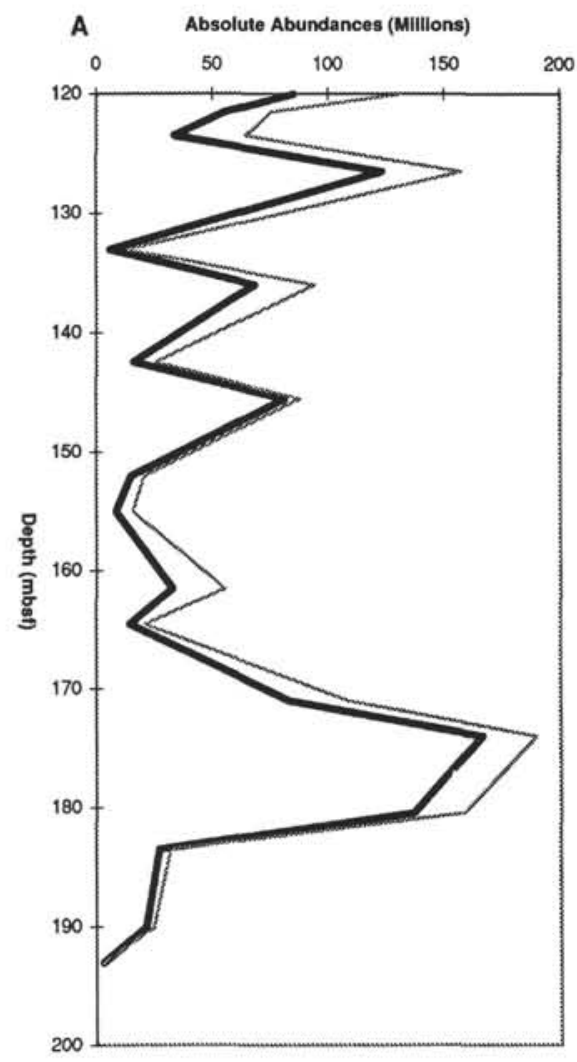

B

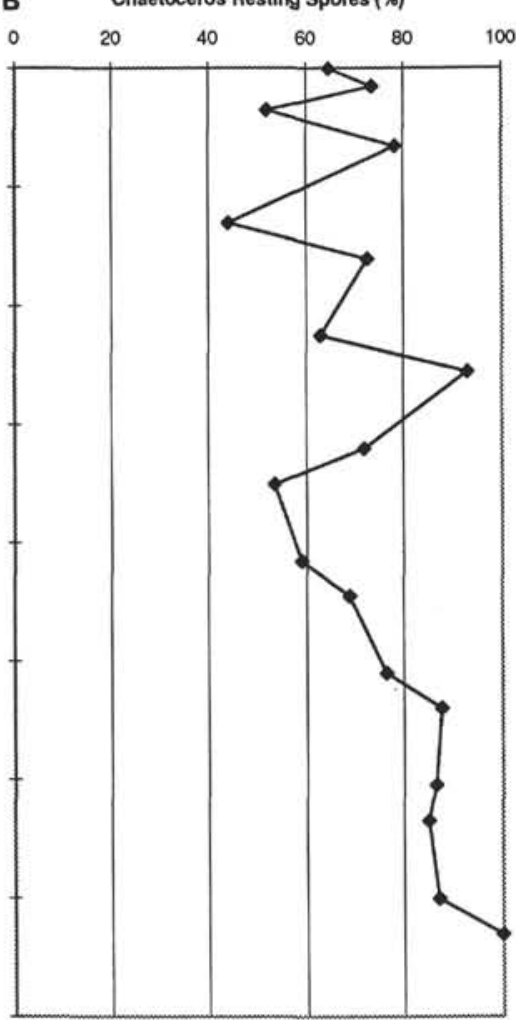

Figure 4. Diatoms in biosiliceous Interval 3. A. Absolute abundances. Heavy line denotes Chaetoceros resting spores. B. Percentages of Chaetoceros resting spores.

\section{Resting spore group distribution (\%)}

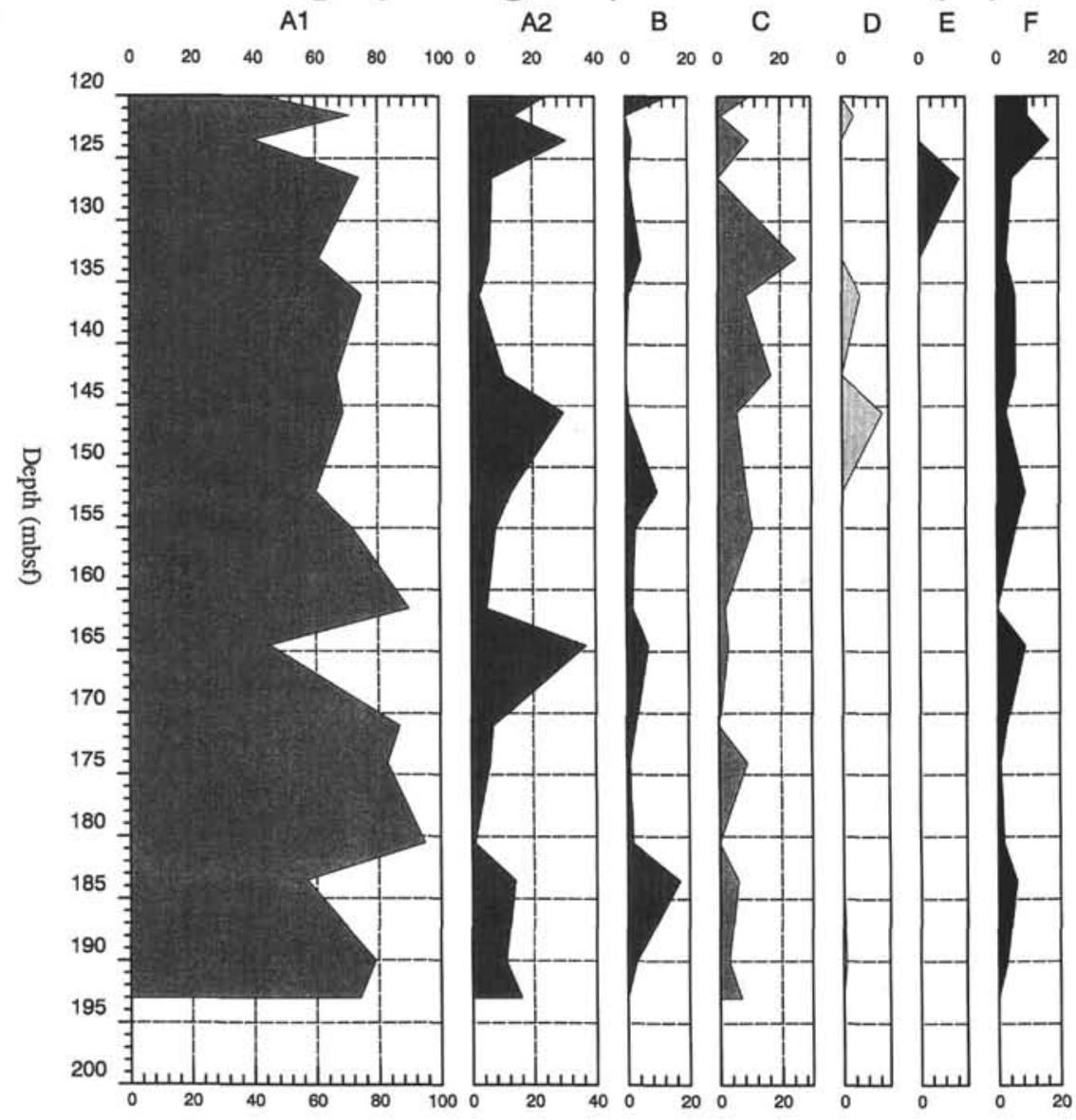

Figure 5. Percentages of different groups of Chaetoceros resting spores through the biosilica-rich interval. 
etative cells are preserved in the sediment record. After this initial diatom flora is established, other diatom taxa start occurring, but Chaetoceros-type diatoms remain the dominant component. The percentage distribution of resting spores declines as the other diatom taxa are established ( 155 to $198 \mathrm{mbsf}$ ). During the remainder of Interval 3, resting spores fluctuate between about $50 \%$ and $80 \%$. During Interval 2 (Fig. 2), the percentage of resting spores decreases sharply to only about $7 \%$ at 60 mbsf.

\section{CONCLUSION}

The onset of siliceous biogenic deposition at ODP Site 907 is dated to middle middle Miocene (13.7 Ma; Koç and Scherer, this volume). Baldauf (1986) suggests a major change in oceanic circulation just prior to this time, based on a decrease in the quality of diatom preservation and the occurrence of numerous hiatuses at about the early/middle Miocene boundary in the North Atlantic. In the middleand high-latitude North Atlantic (Baldauf, 1986) and in the Norwegian Sea (ODP Site 907), middle Miocene sediments are enriched with biosilica. However, during the early late Miocene and earliest Pliocene interval the North Atlantic is generally devoid of diatoms. A variable biosilica production continued in the Norwegian Sea (ODP Site 907) throughout this period. Since about $4 \mathrm{Ma}$, sediments of the middle North Atlantic have been enriched with diatoms. This interval corresponds to very sporadic occurrence of diatoms in the Norwegian Sea (ODP Site 907).

Surface water productivity of the Norwegian-Greenland Seas changed stepwise as the surrounding land masses became glaciated. The change from diatom-rich sediment to a sediment with variable diatom content corresponds to the first IRD record at Site 907 at about $10 \mathrm{Ma}$. This suggests that the paleoceanographic conditions in the Norwegian-Greenland Seas changed and affected surface water productivity as ice sheets started growing in the surrounding land masses. From $2.9 \mathrm{Ma}$ onward there is an increase in IRD content, suggesting increased glaciations. This interval consists of very sporadic occurrences of diatoms or is mainly barren, indicating rather severe conditions for diatom productivity. It is envisaged that the Iceland Plateau was mostly sea-ice covered during the last $2.9 \mathrm{Ma}$.

A gradual increase in diatom abundance during an interval of less than $10 \mathrm{~m}$, (comparable to approximately $0.5 \mathrm{~m} . \mathrm{y}$.; Koç and Scherer, this volume) from sediments barren of diatoms to diatom-rich sediments are recorded. During this initial phase, Chaetoceros spores totally dominate the assemblage. Thereafter, Chaetoceros spores make up at least more than $40 \%$ of the assemblage, indicating highly productive surface waters. The diatom and Chaetoceros spore abundance decrease much more gradually at the end of the diatom-rich sequence, through Interval 2, compared to the initial phase. However, after pulses of diatom-rich sediment with gradually lower Chaetoceros spore contents, diatoms disappear from the sediments at Site 907.

Because of the uncertainties in the classification of diatom resting spores (and especially the problems of relating fossil diatom genera to resting spores; Hargraves, 1986) and the fact that resting spores are quite often lumped together under categories such as Chaetoceros resting spores, it is difficult to draw ecological interpretations based on the fluctuations of these diatom groups. Future studies will, hopefully, increase information on the ecology of the individual groups.

\section{ACKNOWLEDGMENTS}

This paper was improved after careful review by Jack Baldauf and John Barron. Astri Dugan, Turid Winje, Hans C. Seip, and Tadeusz Gladczenko are thanked for excellent technical assistance.

\section{REFERENCES}

Abrantes, F., 1988. Diatom assemblages as upwelling indicators in surface sediments off Portugal. Mar, Geol., 85:15-39.

Akiba, F., 1986. Middle Miocene to Quaternary diatom biostratigraphy in the Nankai trough and Japan trench, and modified lower Miocene through Quaternary diatom zones for middle-to-high latitudes of the North Pacific. In Kagami, H., Karig, D.E., Coulbourn, W.T., et al., Init. Repts. DSDP, 87: Washington (U.S. Govt. Printing Office), 393-481.

Baldauf, J.G., 1986. Diatom biostratigraphic and paleoceanographic interpretations for the middle and high latitude North Atlantic Ocean. In Summerhayes, C.P., and Shackleton, N.J. (Eds.), North Atlantic Paleoceanography. Geol. Soc. Spec. Publ. London, 21:243-252.

Baldauf, J.G., and Barron, J.A., 1990. Evolution of biosiliceous sedimentation patterns-Eocene through Quaternary: paleoceanographic response to polar cooling. In Bleil, U., and Thiede, J. (Eds.), Geological History of the Polar Oceans: Arctic Versus Antarctic: Dordrecht (Kluwer Academic), 575-607.

Berger, W.H., 1976. Biogenous deep-sea sediments: production, preservation, and interpretation. In Riley, J.P., and Chester, R. (Eds.), Chemical Oceanography (Vol. 5): London (Academic Press), 265-388.

Broecker, W.S., and Peng, T.-H., 1982. Tracers in the Sea: Palisades, NY (Lamont-Doherty Geol. Observ.).

Eldholm, O., Thiede, J., Taylor, E., et al., 1987. Proc. ODP, Init. Repts., 104: College Station, TX (Ocean Drilling Program).

Hargraves, P., 1979. Studies on marine plankton diatoms, IV. Morphology of Chaetoceros resting spores. Nova Hedwigia Beih., 64:99-120.

- 1986. The relationship of some fossil diatom genera to resting spores. In Ricard, M. (Ed.), Proc. 8th Int. Diatom Symp., Paris, Aug. 27Sept. 1, 1985, 67-80.

Heath, G.R., 1974. Dissolved silica in deep sea sediments. In Hay, W.W. (Ed.), Studies in Paleo-oceanography. Spec. Publ.-Soc. Econ. Paleontol. Mineral., 20:77-93.

Kaland, P.E., and Stabell, B., 1981. Methods for absolute diatom frequency analysis and combined diatom and pollen analysis in sediments. Nord. J. Bot., 1:697-700.

Lisitzin, A.P., 1972. Sedimentation in the World Ocean, with Emphasis on the Nature, Distribution and Behavior of Marine Suspensions. Spec. Publ.Soc. Econ. Paleontol. Mineral., 17.

Margalef, R., 1978. Life-forms of phytoplankton as survival alternatives in an unstable environment. Oceanol. Acta, 1:493-509.

Myhre, A.M., Thiede, J., Firth, J.V., et al., 1995. Proc. ODP, Init. Repts., 151: College Station, TX (Ocean Drilling Program).

Pokras, E.M., 1986. Preservation of fossil diatoms in Atlantic sediment cores: control by supply rate. Deep-Sea Res. Part A, 33:893-902.

Pokras, E.M., and Molfino, B., 1986. Oceanographic control of diatom abundances and species distributions in surface sediments of the tropical and southeast Atlantic. Mar. Micropaleontol., 10:165-188.

Sancetta, C., 1982. Distribution of diatom species in surface sediments of the Bering and Okhotsk Seas. Micropaleontology, 28:221-257.

Sancetta, C., Heusser, L., and Hall, M.A., 1992. Late Pliocene climate in the Southeast Atlantic: preliminary results from a multi-disciplinary study of DSDP Site 532. Mar. Micropaleontol., 20:59-75.

Schink, D.R., Fanning, K.A., and Pilson, M.E.Q., 1974. Dissolved silica in upper pore waters of the Atlantic Ocean floor. J. Geophys. Res., 79:2243-2250.

Schrader, H.-J., and Fenner, J., 1976. Norwegian Sea Cenozoic diatom biostratigraphy and taxonomy. In Talwani, M., Udintsev, G., et al., Init. Repts. DSDP, 38: Washington (U.S. Govt. Printing Office), 921-1099.

Stockwell, D.A., and Hargraves, P.E., 1986. Morphological variability within resting spores of the marine diatom genus Chaetoceros Ehrenberg. In Ricard, M. (Ed.), Proc. 8th Int. Diatom Symp., Paris, Aug. 27-Sept. 1, $1985,81-96$.

\author{
Date of initial receipt: 7 July 1995 \\ Date of acceptance: 11 December 1995 \\ Ms 151SR-137
}



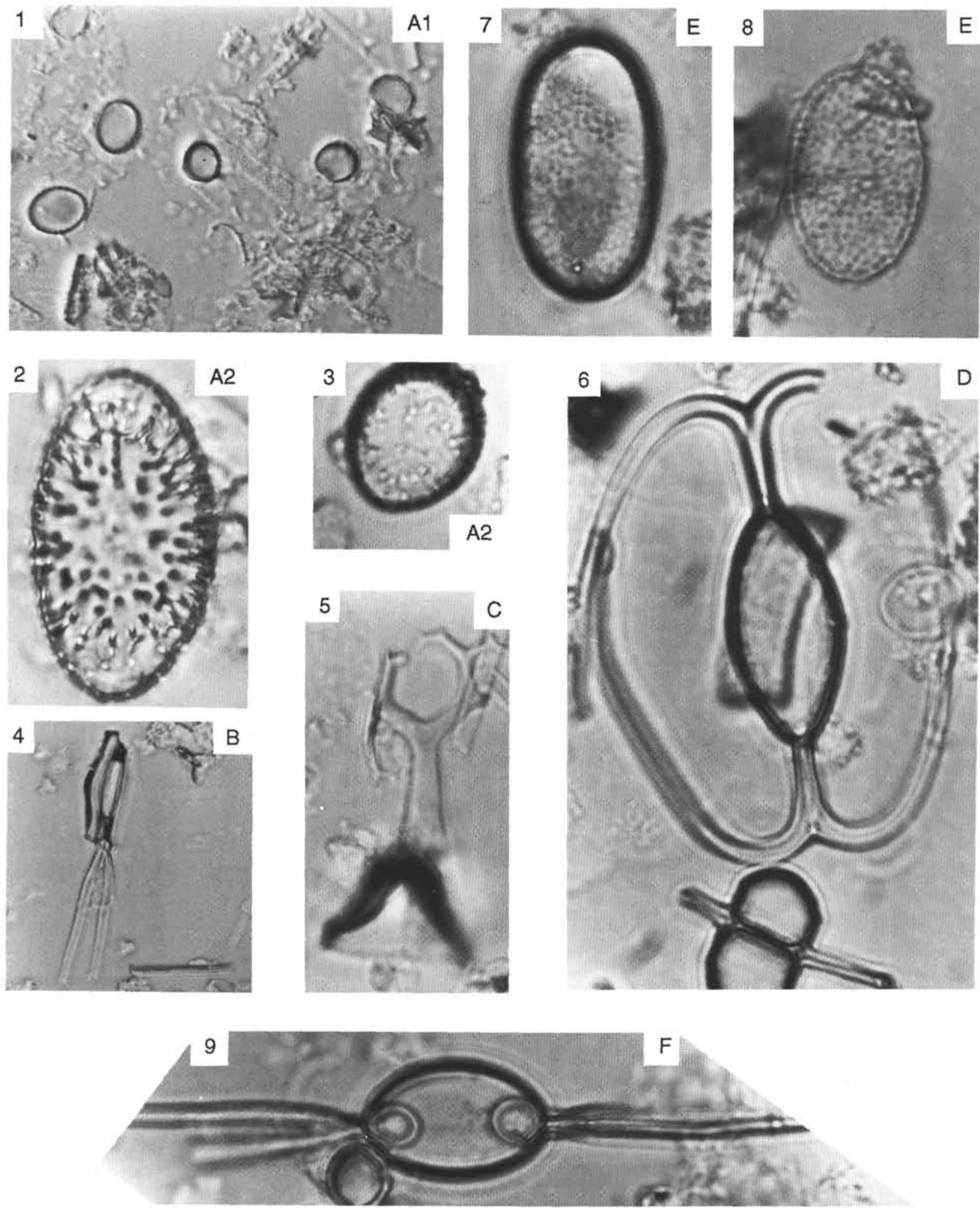

Plate 1. Resting spores representing Groups A through F from Hole 907A. All figures 2500×, except Figure 1 is $1500 \times$ and Figure 4 is $1000 \times$. 1. Group A1; smooth surface, Sample 151-907A-19H-4, 75-76 cm. 2 and 3. Group A2; surface with spines/ridges. (2) from Sample 151-907A-15H-4, 74-75 cm; (3) from Sample 151-907A-16H-4, 74-75 cm. 4. Group B; with setae, Sample 151-907A-20H-4, 74-75 cm. 5. Group C; Chaetoceros/Pterotheca-type, Sample 151$907 \mathrm{~A}-15 \mathrm{H}-2,74-75 \mathrm{~cm}$. 6. Group D; C. cinctus type, Sample 151-907A-16H-4, 74-75 cm. 7 and 8. Group E; rough surface, Sample 151-907A-14H-4, 73-74 cm. 9. Group F; other, Sample 151-907A-16H-4, 74-75 cm. 

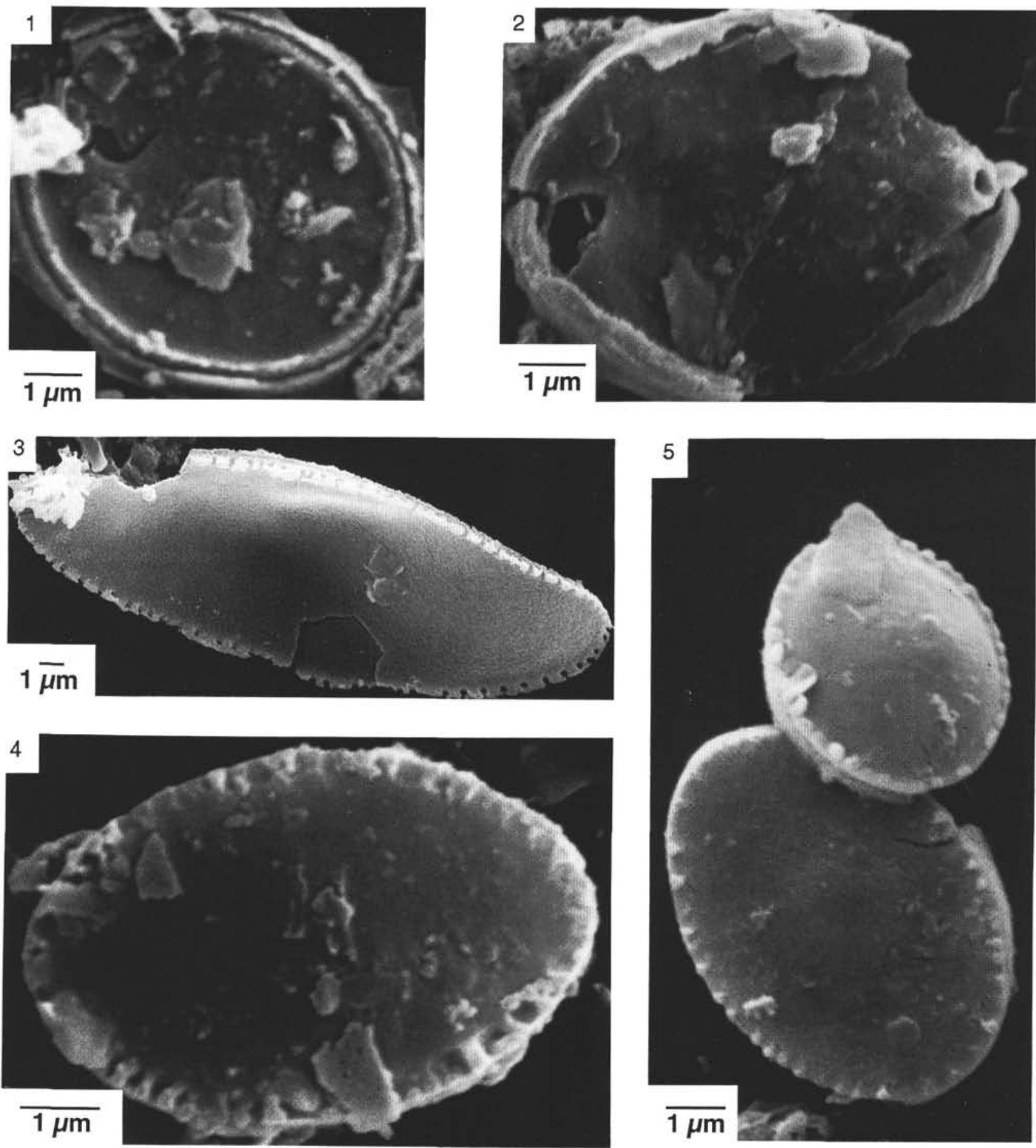

Plate 2. SEM photographs of Chaetoceros resting spores of Group A1 from Sample 151-907A-19H-4, 75-76 cm. 1. Smooth surface, no granules at the margin. 2. Smooth surface, no granules at margin. Note thickened protrusion at right hand side of spore (labiate-like process?). 3. Elongate resting spore with smooth surface and broad "teeth" at margin. 4. Round to elongate spore with smooth surface and "teeth"/granules at margin. 5. Smooth surface and granules at margin. 

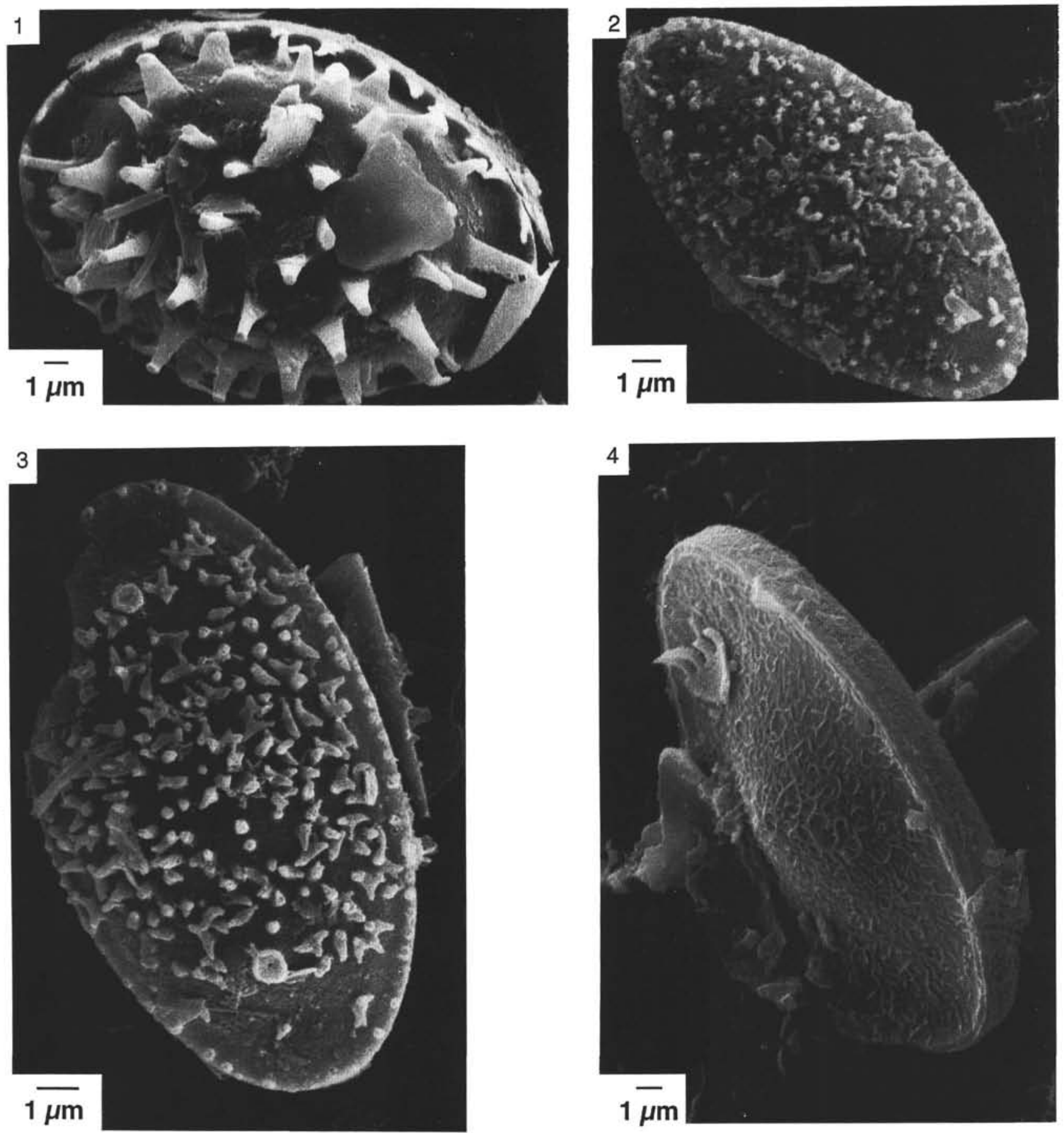

Plate 3. SEM photographs of Chaetoceros resting spores of Group A2 (and possibly Groups E and F) from Sample 151-907A-19H-4, 75-76 cm. 1. Group A2, with spines. 2. Group A2 or E; rough surface with granules at margin. 3. Group A2 or E; rough surface with granules at margin. Note circular pores near both ends. 4. Group F or E; rough? surface, but finer than in (2) and (3), with no granules at margin. 

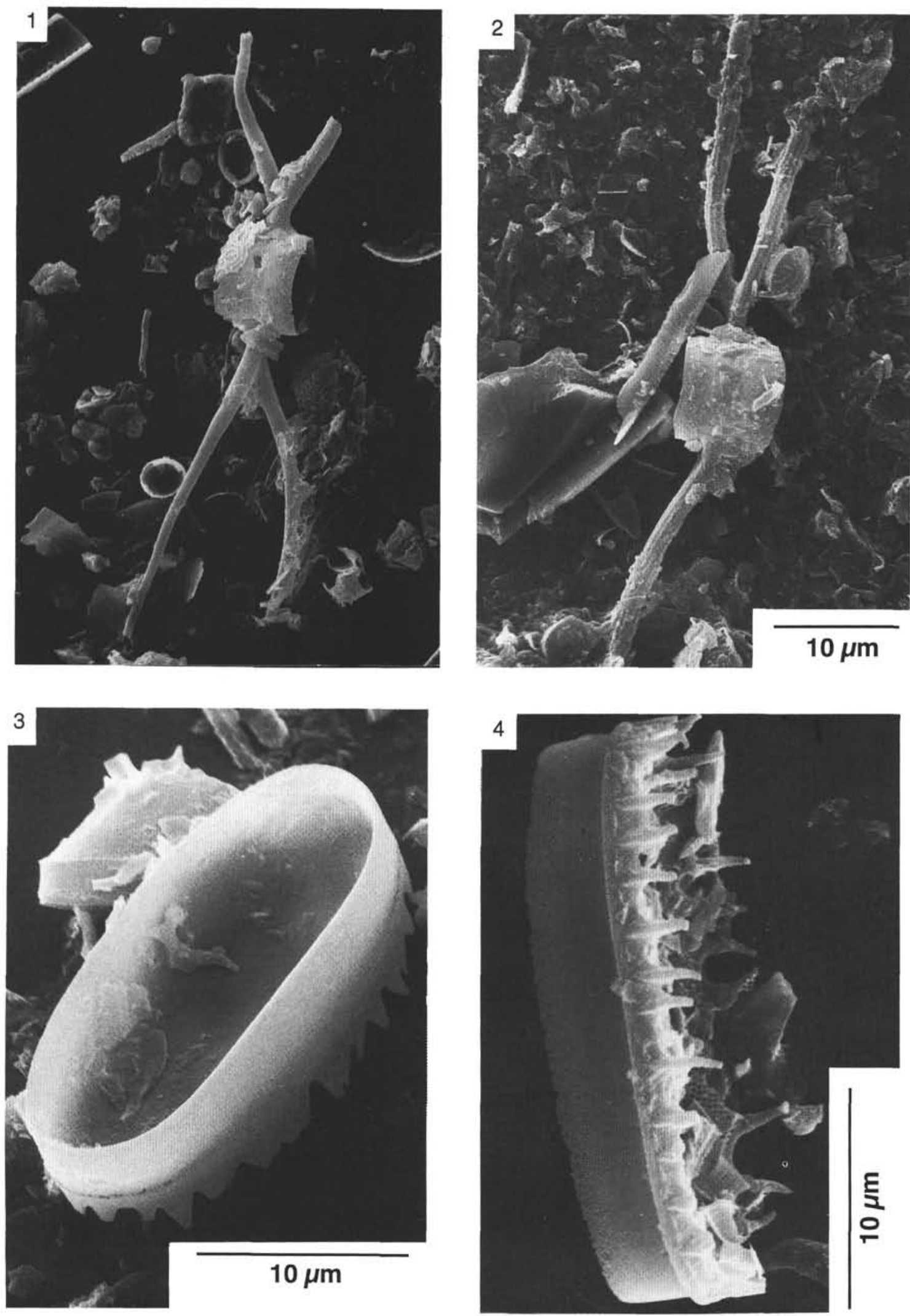

Plate 4. SEM photographs of Chaetoceros resting spores of Group B and F from Sample 151-907A-19H-4, 75-76 cm. 1 and 2. Group B; with setae. 3. Group F; with broad, pointed spines in a continuous band at margin. 4. Group F; with single row of spines along the margin. 